\title{
The Convict and the Compensation Law
}

\author{
Warren L. Hanna*
}

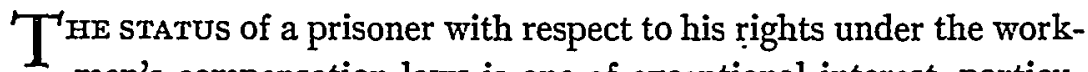
men's compensation laws is one of exceptional interest, particularly at the present time when recent legislation and the increased use of convicts in connection with the war effort have served to focus attention upon the subject.

The compensation problems of the prisoner are mainly concerned with whether he is an employee under the workmen's compensation law and, if so, whether he has a right to prosecute a claim for benefits before state and federal commissions. Stated more concisely, these are questions of the prisoner's status (1) as an employee, and (2) as a litigant.

\section{Status As Employee}

\section{A. General Considerations}

Contractual Basis Of Employer-Employee Relationship-Generally speaking, eligibility for compensation benefits depends upon the existence of an employer-employee relationship. ${ }^{1}$ This relationship, under Labor Code provisions, ${ }^{2}$ is contractual and must be founded upon an agreement for hire, though such an agreement may be implied.

Prisoner's Status Governed by Statutory Rules-The right of a prisoner to workmen's compensation benefits is therefore subject to the general requirement that his services must have been performed under a contract of hire, rather than on an involuntary or compulsory basis. His right to benefits, like that of others rendering service, also depends upon whether or not he is excluded from the coverage of the

*A.B. 1917, University of North Dakota; LL.B. 1923, M.A. 1924, University of Minnesota; Member of San Francisco Bar; General Referee, California Industrial Accident Commission 1931-1943; Author of Industriar Accident Commission Practice ANd Procedure; Editor of: California Compensation Cases; Opinions of Attorney General of the State of California; California Workmen's Compensation Laws Annotated.

\footnotetext{
1 McBurney v. Industrial Acc. Com. (1934) 220 Cal. 124, 30 P. (2d) 414, 20 I.A.C. 211.

2 CaL. LaBos Code $\$ 3351$.
} 
law by specific statutory provision. A review of the pertinent statutes is therefore essential.

\section{B. Pertinent Statutes}

Labor Code Provisions-Division IV, Part I, Chapter 3 of the Labor Code contains Article 2, entitled "Employees", which includes the following sections:

3351. "Employee" means every person in the service of an employer under any appointment or contract of hire or apprenticeship, express or implied, oral or written, whether lawfully or unlawfully employed .....

3352. "Employee" excludes:

(f) Any convict whose labor is used by the State Highway Commission on State Highways or roads.

Penal Code Provisions-In Chapter 5 of Part 3, Title 1, the Penal Code covers the subject of "Employment of Prisoners." In addition to general provision for the work to be done by inmates in and about the various penal institutions, the chapter contains a number of special provisions in respect to services to be performed for persons or agencies not connected with the prisons. Article 1 of this chapter is entitled "Employment of Prisoners Generally" and includes the following section:

$2700 .^{3}$ The Department of Corrections shall require of every ablebodied prisoner imprisoned in any State prison as many hours of faithful labor in each day and every day during his term of imprisonment as shall be prescribed by the rules and regulations of the Director of Corrections.

******

Nothing in this section or in Section 3323 of this code is intended to restore, in whole or in part, the civil rights of any prisoner. No prisoner compensated under this section or Section 3323 shall be considered as an employee or to be employed by the State or the Department of Corrections, nor shall any such prisoner come within any of the provisions of the Workmen's Compensation Insurance and Safety Act of 1917, now codified as Division 4 and Division 5 of the Labor Code, or be entitled to any benefits thereunder whether on behalf of himself or of any other person.

Title 1, Part 3, Chapter 5 of the Penal Code also contains Article 4 entitled "Employment at Road Camps," in which are found the two following sections:

3 As amended by Cax. Stats. 1945, ch. 90. 
2760. The Department of Public Works of the State of California may employ or cause to be employed, prisoners confined in the State prisons in the construction, improvement and maintenance of any State highway.

2766. This article is not intended to restore, in whole or in part, the civil rights of any prisoner used hereunder and said article shall not be so construed. No prisoner so used on the State highway or roads shall be considered as an employee or to be employed by the State Highway Commission, nor shall any such prisoner come within any of the provisions of the Workmen's Compensation Insurance and Safety Act of 1917 or be entitled to any benefits thereunder whether on behalf of himself or that of any other person.

Article 5 of the same chapter is entitled "Employment in Public Parks, Forests, Etc." and includes the two following sections:

2780. Any department, division, bureau, commission or other agency of the State of California or the Federal government may use or cause to be used convicts confined in the State prisons to perform work necessary and proper to be done by them at camps to be estabhished under this article. The board ${ }^{4}$ may enter into contracts for the purposes of this article.

2791. This article is not intended to restore, in whole or in part, the civil rights of any convict used hereunder, and said article shall not be so construed. No convict so used shall be considered as an employee or be employed by the board ${ }^{5}$ or the agency involved, nor shall any such convict come within the provisions of Divisions 4 and 5 of the Labor Code or be entitled to any benefits thereunder whether on behalf of himself or that of any other person.

Article 6 of the same chapter is entitled "Employment in Farm Work and Fighting Fires", and includes the following section:

2802. Prisoners whose temporary removal from prison is authorized by the Adult Authority pursuant to Section 2800 may contract with any person, firm, association or corporation, for the performance of labor in the producing or harvesting of crops. Such contracts may be either written or oral, but shall be upon the following conditions: (2) That the prisoner shall be considered an employee within the meaning of the workmen's compensation laws of this state, ...."

Included in Part 3 of the Penal Code is Title 4, entitled "County Jails," and which contains the following section:

4017. Persons confined in the county jail under a final judgment of imprisonment rendered in a criminal action or proceeding, may be

4 The State Board of Prison Directors.

5 Ibid. 
required by an order of the board of supervisors to perform labor on the public works or ways in the county.

The phrase "labor on the public works" as used in this section shall include among other things clerical and menial labor in the county jail or in the camps maintained for the labor of such persons upon the ways in the county.

\section{Nature of Service as a Criterion}

Nature of Services Rendered-An examination of the activities which a prisoner may perform during the period of incarceration discloses two general types of service. These are:

\section{Services for the institution of confinement, including}

(a) Services usually performed within its walls, and required by its authorities as an ordinary incident of the sentence of imprisonment.

(b) Services usually performed outside its walls, for which some remuneration is allowed in money or reduction of time to be served, and for which type of service the prisoner is sometimes permitted to volunteer.

2. Services for persons or agencies other than the institution of confinement, always performed outside institution walls under special statutory authority, and always with remuneration to the prisoner from the persons or agencies for which the work is done.

Services for Institution of Confinement-It is well settled that service performed for the institution of confinement does not constitute the prisoner an employee, nor qualify him for workmen's compensation benefits. As to those in group 1(a) above, it is clear that the rendition of service is purely compulsory and without the element of volition incidental to any contract of hire. ${ }^{b}$ The employer-employee relationship is not created, regardless of whether the work is done inside or outside institution walls. As to those in group 1(b), the same rule applies. Although there appears to be no decision on this point as to state convicts, the California Commission has held repeatedly that county prisoners who work on public highways or in county road camps are not employees within the meaning of the workmen's compensation law. Nor is the fact that the work may

6 Even one who worked to avoid the bread and water treatment which he understood to be the alternative was held not to be an employee, Stringer v. City of Tulare (1941) 6 Cal. Comp. Cases 175; so, also, with one who chose to work out a fine rather than go to jail, Richardson v. City of Santa Ana (1941) 6 Cal. Comp. Cases 229.

7 Underwood v. Industrial Acc. Com. (1933) 19 I.A.C. 136 (writ of review denied by District Court of Appeal) ; Collins v. Los Angeles County (1933) 19 I.A.C. 2; Slinger 
bring certain remuneration to the prisoner or his dependents, ${ }^{8}$ or the fact that there was an element of "volition" as to whether the prisoner would serve his term in jail or in the road camp ${ }^{9}$ sufficient to create a status of employment.

Services for Other Persons or Agencies-As to those in the second group, the rule is that such prisoners may, for the purposes of the workmen's compensation law, be employees of the person or agency (other than the institution of confinement) for which the work is done, if there is no statute precluding such a status. ${ }^{10} \mathrm{Each}$ such situation therefore depends upon its particular facts and the existence or non-existence of a statutory ban in respect thereto.

\section{County Jail Prisoners}

Jail Inmates Are Not Employees-All county and city jail prisoners fall within the first classification, and therefore do not acquire the status of employees under the compensation law. All service of such prisoners is rendered for the institution of confinement, and there appears to be no statutory authority for permitting the rendition of service by such prisoners to outside persons or agencies. ${ }^{11}$ Furthermore, the many decisions of the Commission with respect to service by county jail prisoners on public highways and in road camps have set this question at rest. ${ }^{13}$

\section{E. State Convicts}

Who May Secure Services of State Prisoners-It becomes apparent, upon further study, that the second classification mentioned above is made up of none other than prisoners in state institutions. An analysis of statutory provisions discloses the fact that the services of such convicts can be rendered to outside persons or agencies under three different conditions, as follows:

v. County of Riverside (1931) 17 I.A.C. 61; Boyd v. County of San Bernardino (1924) 11 I.A.C. 56; cf. Jackson v. Calif. George Junior Republic (1922) 9 I.A.C. 33.

8 Coffey v. Industrial Acc. Conl. (1937) 2 Cal. Comp. Cases 56 (writ of review denied by Supreme Court); Underwood v. Industrial Acc. Com., supra note 7.

${ }^{\circ}$ Smith v. Industrial Acc. Com. (1938) 3 Cal. Comp. Cases (writ of review denied by Suprene Court).

10 California Highway Conmission. v. Industrial Acc. Com. (1926) 200 Cal. 44, 251 Pac. 808, 13 I.A.C. 230, 49 A.L.R. 1377.

11 Section 4017 of CAx. PEN. CODE does authorize work by county jail prisoners on county roads and public works, but does not provide for services to persons or agencies other than the county itself.

${ }^{12}$ See cases cited supra notes 7,8 , and 9. 
1. Services for the California Highway Commission in the construction, improvement or maintenance or any state highway. ${ }^{13}$

2. Services for any state or federal agency in parks, forests or camps. ${ }^{14}$

3. Services in harvesting of crops or fighting fires (limited by law to the duration of the emergency)..$^{15}$

Convicts Working for State and Federal Agencies-The status of the convicts performing services for the Highway Commission (Group 1 above) or for any state or federal agency in parks, forests or camps (Group 2 above) is fixed by statute. Penal Code provisions specifically preclude such convicts from acquiring the status of employees under the workmen's compensation law. ${ }^{10}$ The Labor Code has a similar exclusion of convicts rendering service for the Highway Commission. ${ }^{17}$

Past Status of Convicts Engaged in Crop Harvesting-The fact that the status of convicts engaged in crop harvesting has not heretofore ${ }^{18}$ been covered by a similar statute of exclusion has been deemed significant, in view of the reasoning of the supreme court in California Highreay Commission v. I.A.C..$^{19}$ And the Commission has, in fact, held in a recent decision ${ }^{20}$ that a convict injured while engaged in crop harvesting was entitled to compensation benefits, following a line of reasoning which may be summarized substantially as follows:

1. Convicts are released from prison confinement to engage in crop harvesting work only by special parole issued for that purpose by the State Board of Prison Terms and Paroles.

2. That board is empowered by law (Penal Code section 3054, formerly section 673 ) to restore to such parolees, to a limited extent, civil rights otherwise suspended during their terms of imprisonment.

3. Whether or not there has been restored to a parolee the right to enter into a contract of employment is a matter to be determined from the terms of the parole issued in each individual case.

4. Ordinarily, however, where the parolee is granted his limited parole for the specific purpose of entering private crop-harvesting

13 Cat. Pen. Code $\$ 2760$.

14 CaL. Pen. Code $\$ 2780$.

15 CAL. PEN. CODE $\$ \S 2800-2807$ incl.

16 CAL. Pen. CODE $\$ \$ 2766$ and 2791.

17 Cal. LaBor CODE $\$ 3352$ (f).

18 Prior to the enactment of Penal Code section 2802 effective Sept. 15, 1945.

${ }^{10}$ Supra note 10.

${ }^{20}$ Brien v. American Crystal Sugar Co. (Knightsen Camp) and Employers' Liability Assurance Corporation, S.F. No. 81760 . 
employment, restoration of the restricted right to enter such employment is to be implied from the general tenor of the parole.

5. If it reasonably appears from the parole granted in a particular case that it was the intention of the Parole Board to restore to a parolee for a limited time the right to enter into a contract of employment with a particular person or class of persons, such parolee will be deemed an employee within the purview of the workmen's compensation law, if not otherwise excluded by the provisions of the Labor Code, by reason of engaging in agricultural activities.

Future Status of Convicts Engaged in Crop Harvesting-When the 1945 legislature adopted Penal Code sections 2800-07,21 it specifically declared that a prisoner performing labor for any person, firm, association or corporation in the producing or harvesting of crops "shall be considered an employee within the meaning of the workmen's compensation laws of this State"..$^{22}$ Thus, the status of a prisoner injured under such circumstances is settled for the remainder of the period during which the legislation remains in effect. ${ }^{23}$

Convicts Engaged in Fire Fighting-The status of a convict engaged in fire fighting is more obscure. The provisions of Penal Code section 2802 (2), declaring the existence of an employment status under the workmen's compensation laws, appear to apply only to prisoners engaged in crop producing or harvesting, and not to those engaged in fire fighting. It must be concluded, therefore, that fire fighting services, if performed in a forest, park or camp for state or federal agency, would come within the ban of Penal Code section 2791 , and the convict thus engaged would be excluded from the protection of the workmen's compensation laws. ${ }^{23 a}$ Inasmuch as the use of convicts for fire fighting purposes by county or local authorities is not expressly sanctioned by the Penal Code, it is improbable that any such arrangement would be entered into by prison officials. In the event that such services were performed for county or local authorities, or for private individuals, there would appear to be no applicable statute of exclusion and such convicts, under limited parole, might be deemed employees within the meaning of the compensation law.

21 As enacted by CaL. Stats. 1945, Ch. 35, representing an expansion of the provisions of former Penal Code section 2715.

22 CAL. PEN. CODE § 2802(2).

23 Sections 2800-07 of the Penal Code are emergency legislation, and will remain in effect only until six montbs after the termination of the war, or until the end of the national emergency, whichever first occurs.

23a The Commission so held in Meyers v. State of California, S. F. No. 93433, 10 Cal. Conip. Cases 217, decided March 19, 1945. 


\section{F. Paroled Convicts}

Status Under Compensation Law-A person released from prison on parole is constructively a prisoner and has the civil status of one. ${ }^{24}$ However, paroled prisoners may be granted a portion of their civil rights by the Parole Board. ${ }^{25}$ While the extent of such restoration may vary in the discretion of the Board, it ordinarily includes the right of the parolee to contract for his services. ${ }^{20}$ Indeed, rehabilitation through such employment is one of the purposes of parole, ${ }^{2 \pi}$ and the promise of an available job is one of the prerequisites for the release of a convict on parole. In every case, then, the terms of the parole are the measure of the parolee's ability to assume the status of an employee, with presumption favoring such a status where there is any ambiguity in the language of the document granting parole.

\section{G. Prisoners of War}

Service by War Prisoners-It is common knowledge that prisoners of war have been used in the performance of certain restricted types of work under conditions prescribed by the federal authorities. There has been no application by such a prisoner for benefits under the state workmen's compensation law, and of course, no determination by the Industrial Accident Commission as to its jurisdiction in such a situation. However, the status of such prisoners as to injuries in the course of work performed in California would appear to be exclusively subject to federal control, particularly in view of the following order issued by the Adjutant General of the United States on behalf of the War Department:

Text of Federal Order-“" 1 . Each prisoner of war engaged in labor for pay will be considered an employee of the United States for the purpose of disability compensation whether he works on a project sponsored by the United States, by a state or subdivision thereof, municipal or private corporation, or by an individual or individuals.

"2. In the event that a prisoner of war sustains injury arising out of and in the course of labor for pay, not caused by the wilful misconduct of the prisoner, or by the intention to bring about injury or death of himself or another, or by his voluntary intoxication, which

24 In re Sanders (1920) 47 Cal. App. 368, 190 Pac. 647.

25 CAL. PEN. CODE $\$ 3054$.

${ }^{26}$ For comment on the status of the paroled prisoner as an employee, see Attorney General Opinion No. 2444 (Calif.), dated Feb. 15, 1913; also see 7 Ops. Cal. Atry. Gen. 67 for Opinion No. 45-278 dated Jan. 31, 1946.

27 In this connection, note the provisions of CAL. PEN. Code $\$ 3057$. 
prevents him from continuing work for pay, he may be paid at the discretion of the Secretary of War by the War Department at the rate of 40 cents per day (a) until he is able to engage im labor for pay or (b) until his repatriation or (c) until his death. The occurrence of any one of these three possibilities will terminate disability payment.

"3. Claims for compensation under these regulations will be considered by a board of officers convened by order of the commanding officer of the prisoner of war camp involved to investigate and make recommendations in the premises. $* * * * * 228$

\section{Status As Litigant}

\section{A. Preliminary Considerations}

Right of Prisoner to Present Compensation Claims-Regardless of the prisoner's status as an employee, he is faced with the equally fundamental question of whether he is legally able, durmg the period of his imprisonment, as well as during periods of parole, to prosecute his claim for compensation before the appropriate tribunal.

Practice of Commissions and of Courts-In approaching this problem, there is to be noted, on the one hand, the long-standing practice of state and federal compensation commissions in permitting the holding of hearings upon claims by state and county prisoners, and the further custom of making decisions on the merits in such cases. On the other hand, the prosecution of litigation by convicts in the civil courts is unknown, and it would seem important to ascertain whether there may be more reason for this divergency of practice than the mere ability or willingness of the commissions to bring their court to the prisoner.

\section{B. Pertinent Statutes}

Penal Code Provisions on Civil Death-The Penal Code contains an entire chapter on "Civil Death of Prisoners." This is Chapter 3 of Title 1, Part 3, and the provisions of Article 1 thereof, entitled "Civil Death" are as follows:

2600. A sentence of imprisonment in a State prison for any term less than life suspends all the civil rights of the person so sentenced, and forfeits all public offices and all private trusts, authority or power during such imprisonment. But the board (State Board of Prison Directors) may restore to said person during his imprisonment such

28 This order was published on Aug. 21, 1943, under the following number: "AG 383.6 (14 Aug. 43) OB-P-SPMCA-MB-A, and over the signature of J. A. Ulio, Major General. 
civil rights as the board may deem proper, except the right to act as a trustee, or hold public office or exercise the privilege of an elector or give a general power of attorney.

2601. A person sentenced to imprisonment in the State prison for life is thereafter deemed civilly dead. But the board (State Board of Prison Directors) may restore to such person during his imprisonment such civil rights as the board may deem proper, except the right to act as a trustee, or hold public office, or exercise the privilege of an elector, or give a general power of attorney.

2602. A person sentenced to death is deemed civilly dead during the existence of the death sentence.

2603. The provisions of the last three preceding sections must not be construed to render the persons therein mentioned incompetent as witnesses by affidavit or deposition in a civil case or proceeding or by affidavit or deposition or personally in a criminal case or proceeding, or incapable of making a will, or incapable of making and acknowledging a sale or conveyance of property.

2604. No conviction of any person for a crime works any forfeiture of any property, except in cases in which a forfeiture is expressly imposed by law; and all forfeitures to the people of the State, in the nature of a deodand, or where any person shall flee from justice, are abolished.

Penal Code Provisions on Restoration of Civil Rights-Chapter 8 of Title 1, Part 3, in Article 3 dealing with the subject of "Parolees," contains the following sections:

3054. The board [Board of Prison Terms and Paroles] may permit paroled persons civil rights, other than the right to act as a trustee, or hold public office, or exercise the privilege of an elector, during the term of such parole. The scope or extent of such civil rights shall be determined by such board as, in the judgment of such board, is for the best interest of society and such paroled person.

3055. The board (Board of Prison Terms and Paroles) shall, at the time of permitting such civil rights, make a permanent record thereof, and such record shall be a public record for the benefit of all persons requiring information in that behalf.

Chapter 3.5 of Title 6, Part 3 deals with the procedure for "restoration of rights and application for pardon" and provides for a period of rehabilitation as a preliminary to an application for a pardon. After determination by a court that there has been a proper period of rehabilitation, a certificate to that effect is issued. Among its purposes is that described by the following provision:

4852.15. From the time it is filed, the certificate of rehabilitation shall operate to restore to the person to whom it is issued his civil 
rights, except the right to act as a trustee and the right to hold public office.....

Chapter 4 of Title 6 of Part 3 deals with the effect of a full pardon, and contains the following provision in respect to civil rights:

4853. In all cases in which a full pardon has been granted by the Governor of this State or will hereafter be granted by said Governor to a person convicted of an offense to which said pardon applies, it shall operate to restore to such convicted person, all the rights, privileges, and franchises of which he has been deprived in consequence of said conviction or by reason of any matter involved therein; .....

The provisions of Penal Code sections 2700, 2766 and 2791, supra, assert that the performance of work by convicts whose services are utilized in state prisons or institutions, on state highways, or in parks, forests and camps, shall in no way operate to restore their civil rights.

Civil Code Provision on Civil Rights-The only other pertinent statutory provision with respect to the loss or restoration of civil rights is found in the Civil Code and reads as follows:

1556. All persons are capable of contracting, except minors, persons of unsound mind, and persons deprived of civil rights.

\section{Nature of Civil Rights}

Definition of Civil Rights - While the statutes provide that imprisonment in a state prison shall result in "civil death"29 or in the suspension of all "civil rights"30 during such imprisonment, they fail to supply us with a definition of either term. Fortunately, an opinion of the California supreme court suggests that civil rights are those "whose exercise or enjoyment depends upon some provision of positive law," and that civil death imports a deprivation of all such rights. ${ }^{31}$

The Right to Sue Is a Civil Right-Measured by this judicial yardstick, the right to prosecute litigation is a civil right. It cannot be denied that the right to commence and carry on legal proceedings is one which, in California, depends entirely upon statutory provision and authority. It follows, therefore, that the right to sue is one of the

29 Cal. Pen. Code $\$ \$ 2601$ and 2602.

30 CAL. Pen. Code $\$ 2600$.

31 Estate of Donnelly (1899) 125 Cal. 417, 419, 58 Pac. 61. 
rights referred to whenever the cited statutes speak of "civil rights," and is necessarily embraced among those rights, the loss of which in their entirety amounts to "civil death."

\section{The General Rule and Its Antecedents}

The Roman Lare-The Corpus Juris of Justinian imposed the loss of the status libertatis on one condemned of crime. This meant not only the loss of liberty, but the loss of juristic personality and civil rights as well. ${ }^{32}$

The Common Lare-A convict under the common law was deprived of his right to sue, although he did not lose all civil rights. With respect to civil death under the common law, it has been said: "The attainted person was not divested of his lands . . ; he could devise them, subject only to the right of entry for the forfeiture and could be either a grantor or a grantee, and the grant would be good against all persons other than the king... He could be sued, but could not sue; he could contract, but could not require the courts to aid him in enforcing his contracts." ${ }^{\prime 33}$

General Rule in the United States-In this country the general rule with respect to the effect of imprisonment upon the right to sue has been well stated in 18 Corpus Juris Secundum, at page 105:

"In jurisdictions where ... the convict does not lose his civil rights as a result of his conviction, it is held that he may sue ... On the other hand, where the convict is regarded as losing his civil rights as a result of his conviction, it is generally held that he cannot sue under such disability, even ... to recover for injuries received during his imprisonment ... It has been held that a convict who has so lost his civil rights can maintain actions which concern his personal liberty and are based on natural rights as distinguished from legal rights."

\section{E. Decisions of the California Courts}

No Decisions Squarely in Point-A review of California cases fails to disclose any decision dealing squarely with the right of a prisoner to sue. The supreme court has held that the right of inheritance is one of the civil rights suspended or extinguished by a sentence of imprisonment in a state penal institution. ${ }^{34}$ The same court,

32 Sohm's Roman Law, Ledlie (1892) 122.

338 R. C. L. 705.

34 Supra note 31. 
in a series of decisions, has also held that "civil death" does not deprive the creditors of a prisoner of the right to hold him to his obligations and liabilities through suit, attachment and execution. ${ }^{35}$

Helpful Appellate Court Decision-Possibly the most helpful decision of the courts with respect to the problem under consideration is that discussed in 5 California Law Review 81, at page 82, as follows:

"The case of Castera v. Superior Court (29 Cal. App. 694) has, however, determined the status of convicts as regards civil actions to which the prisoner is a party. The following three questions are suggested by the case: Can a convict sue, can a convict be sued, and, finally, if he can be sued, can he defend himself? The court held that section 673 (now section 2601) of the Penal Code imposing civil death upon convicts sentenced for life, and section 674 (now section 2600) imposing 'the loss of all civil rights' upon those in state's prison for less than life, did not prevent a convict from being sued although it did prevent the convict from bringing suit. This decision is in accord with the common law rule. The final question, can a convict defend himself if sued, was not decided by the court."

Other Light on the Subject-A most interesting review of the situation with respect to a prisoner's civil rights is found at $2 \mathrm{Cal}$ ifornia Law Review 401, a part of which is as follows:

"A sentence of imprisonment in a state prison for any term less than for life suspends all the civil rights of the person so sentenced, and forfeits all public offices and all private trusts, authority or power during such imprisonment and, if for life, the person is thereafter deemed civilly dead. In substantially these words, California imposes upon her felons, in the nature of a penalty, an incapacity which in many respects resembles the ancient ban of civiliter mortuus. Its true significance is obviously a matter of considerable importance, no longer confined almost entirely within the walls of the prison ... The Supreme Court of California has stated (Estate of Donnelly, 125 Cal. 417) that civil death 'imported a deprivation of all rights whose exercise or enjoyment depends upon some provision of positive law' and held that inheritance was such a right ... The court has declared that these provisions are subject to no exceptions, save those enumerated by the code, such as the right to be a witness in a criminal action, to sell and convey property, and not to be made to suffer an unauthorized injury to the person, or to forfeit his property. The wide extent of this incapacity seems to be strengthened by the nature of

35 In re Estate of Nerac (1868) 35 Cal. 392; Coffee v. Haynes (1899) 124 Cal. 561, 57 Pac. 482; Emmanuel v. Sichofsky (1926) 198 Cal. 713, 247 Pac. 205. 
these exceptions and the fact that the legislature deemed them necessary."

\section{F. The General Rule Applied to California}

Loss of Civil Rights-That the general American rule ${ }^{36}$ will be adopted by the California courts when the question is presented is almost a foregone conclusion, in view of the nature of the applicable statutes and the language of past opinions on related points. Under that rule, California jail prisoners clearly retain the right to sue since they are not deprived of civil rights by law, while penitentiary prisoners, by a parity of reasoning, forfeit the right to sue since California is a jurisdiction in which a state convict "is regarded as losing his civil rights by reason of his conviction. ${ }^{237}$ At least, he must be regarded as having lost all civil rights except the following:

1. Those rights affirmatively enumerated and excepted by the code itself, including (a) the right to be a witness, ${ }^{38}$ (b) the right to make a will ${ }^{39}$ (c) the right to sell and convey property, ${ }^{40}$ (d) the right of freedom from unauthorized injury to his person, ${ }^{41}$ and (e) the right to freedom from forfeiture of his property. ${ }^{42}$

2. Those rights affirmatively restored to the convict by action of (a) the State Board of Prison Directors for any period during which he is confined to prison, ${ }^{43}$ or of (b) the Board of Prison Terms and Paroles for any period during which he may be granted a parole. ${ }^{44}$

Right to Sue Not Excepted-Clearly, the right to sue is not one of the civil rights covered by statutory exception, and it is therefore necessarily removed by the provisions of Penal Code sections 2600, 2601 and 2602. Except in cases of death sentence, it is capable of restoration by special action of the proper authority, either during imprisonment ${ }^{45}$ or parole,$^{46}$ since it is not one of the rights the restoration of which is forbidden by Penal Code sections 2600, 2601 or 3054. It is doubtful, however, whether such a restoration of the right to sue has ever been made in any case during the period of imprison-

${ }^{33}$ Supra note 33.

37 Cal. Pex. CODe sections 2600 to 2604 , inclusive, seem to make the quoted language of the general rule particularly applicable to California.

38 CAL. PEXX. CODE § 2603.

39 Ibid.

40 Ibid.

41 Cal. Pen. Code $\$ 2650$.

42 Ibid. § 2604.

43 Ibid. $\$ \$ 2600$ and 2601.

$4 \cdot \mathrm{Ibid}$. $\$ 3054$ and 3055 .

45 Ibid. $\$ \$ 2600$ and 2601 .

46 Ibid. $\$ 3054,4852.15$, and 4853. 
ment, and the burden would be upon a convict to establish his freedom from such a disability by showing affrmatively the restoration by board action of his right to sue.

Rule Applicable to Commission Cases-No valid distinction can be drawn between the right to sue in civil court and the right to prosecute a claim for compensation before the state industrial accident commission. The Califorma courts have repeatedly declared the commission to be a judicial body exercising judicial functions, and that its decisions and awards are subject to the same general legal principles which circumscribe and regulate the judgments of all judicial tribunals. ${ }^{47}$ Accordingly, it may not assume a jurisdiction which can only be attained through the disregard of specific Penal Code sections with respect to a well-defined class of persons. Nor does there seem to be any sound reason why the same rules do not apply with equal force to the federal compensation commission, although the validity of this contention is not conceded by that body.

\section{G. Filing and Prosecution of Claims}

Right to File a Claim-Granting applicability of the general rule to workmen's compensation proceedings in California, what is to be the practical effect upon a convict's right to file and prosecute a claim? In this connection, it will be perceived that there are embraced in the general right to sue all of its lesser components, including the right to initiate litigation and the right to unaintain it. Necessarily, these subsidiary rights are forfeited whenever the principal right is removed. Therefore, a convict who has not been granted a restoration of his civil right to sue is powerless even to file an application for compensation benefits, whether the injury be one occurring prior to, or during his imprisonment.

Right to Prosecute a Claim-Similarly, the right to prosecute a claim has vanished forever in the case of the convict sentenced to death, and is suspended for the period of imprisonment of convicts serving a lesser sentence. As to those claims on which there has been an attempted filing during imprisonment, the problem of proceeding further is, for all practical purposes, settled before it arises, for the filing itself is a nullity. As to claims validly filed prior to imprison-

$4 \pi$ Pacific Coast Cas. Co. v. Pillsbury (1915) 171 Cal. 319, 153 Pac. 24, 2 I.A.C. 66; Western Metal Supply Co. v. Pillsbury (1916) 172 Cal. 407, 156 Pac. 491, 3 I.A.C. 190; Carstens v. Pillsbury (1916) 172 Cal. 572, 158 Pac. 218, 3 I.A.C. 215; Gouanillou v. I.A.C. (1920) 184 Cal. 418, 193 Pac. 937, 7 I.A.C. 204. 
ment, the right to a hearing and determination by the Commission is merely suspended for the period of loss of civil rights.

Action by Commission-The Commission cannot refuse to file a claim which it does not definitely know to be from a person without civil rights; nor can it refuse to proceed with hearing of the claim of one whom it merely suspects may have lost such rights. But when the Commission has been sufficiently apprised that the would-be litigant lacks the legal right to file or press his claim, whether such information be secured on its own initiative or as a result of objection by the defendant, summary disposition of the matter should be made forthwith. If the claim is found to have been filed during imprisonment by one deprived of the civil right to sue, the application should be stricken and the matter dismissed. If the claim is found to have been filed prior to imprisonment by one subsequently deprived of the right to sue, a closing order should issue ${ }^{48}$ unless the defendant insists that the matter proceed. In the latter event, the defendant is entitled to have the matter heard and determined in the usual way. ${ }^{49}$

\section{H. Statute of Limitations}

General Rules-Running of the statute of limitations against one possessing the right to sue may be postponed by various legal disabilities, including infancy, incompetency and imprisonment. As a rule, imprisonment will not affect the operation of the statute unless expressly recognized as an exception by the terms of the statute. ${ }^{50}$ The burden of proving that he is entitled to the benefit of an exception to the statute of limitations is upon a plaintiff whose pleadings show on their face that his claim is barred..$^{51}$

California Limitations on Compensation Claims-The statute of limitations, as set forth in the workmen's compensation law, expressly suspends the statutory limitations of time in favor of minors and incompetents, but makes no similar exception in respect to prisoners or convicts. ${ }^{52}$ Under standard rules of statutory construction, ${ }^{53}$

${ }^{48} \mathrm{As}$ in Neff v. Lowe Company and Fidelity \& Casualty Company, S. F. No. 22580, in which the Commission issued an order suspending further proceedings for the period of imprisonment.

40 Castero v. Superior Court (1916) 29 Cal. App. 694, 159 Pac. 735.

50) 37 C.J. 1024.

51 New Amsterdam Cas. Co. v. I.A.C. (1924) 66 Cal. App. 86, 225 Pac. 459, 11

I.A.C. 212.

52 CaL. Labor CODE $§ 5408$.

53 The rule of expressio unis est exclusio alterius. 
the failure to recognize imprisonment as a legal disability, in the face of specific statutory mention of other disabilities, would indicate a legislative intention to exclude prisoners from the class of persons entitled to a suspension of the limitations of time. Such a result would also be in accord with the general rule. ${ }^{54}$

California Limitations on Civil Actions-The Code of Civil Procedure suspends the statute of limitations applicable to civil actions during periods of imprisonment. ${ }^{55}$ However, it should be noted that such suspension is explicitly limited to (1) those actions mentioned in Chapters 2 and 3 respectively of Title II of Part Two of that Code, (2) those causes of action which accrue while the person entitled to sue is under the disability of imprisonment or criminal sentence, and (3) those cases where the sentence is for a term less than life.

Applicability of Civil Action Rule to Compensation Claim-The question immediately arises as to whether the Code of Civil Procedure provisions are applicable to proceedings before the Industrial Accident Commisșion. It may be doubted if such is the case, in this instance, at least, for the reasons that (1) It is questionable whether a compensation proceeding is a civil action within the contemplation of the Code of Civil Procedure; (2) This doubt is emphasized by the fact that the Labor Code has established its own separate and complete procedure for the handling of compensation claims, including its own detailed statute of limitations; (3) The Code of Civil Procedure provisions as to the effect of imprisonment are specifically limited to the particular actions mentioned in the above-named chapters of that Code; and (4) The Labor Code has frequently incorporated the provisions of the Code of Civil Procedure in other instanc$\mathrm{es}^{58}$ where it was desirable to do so, and the absence of such an incorporation by reference in this case would seem to indicate a lack of legislative intent to superimpose the Code of Civil Procedure provisions upon a special type of proceeding established and fully provided for procedurally by the Labor Code. ${ }^{55}$ It would seem, therefore, that unless the separately established and independently functioning procedure of the workmen's compensation law is governed by the

\section{Supra note 50.}

55 CaI. Code Crv. Proc. $\$ \S 352$ and 328.

50 CaL. LaBor Code $\$ \S 5308,5311,5316,5506,5600,5601,5954$, and 6144.

57 Again referring to that cardinal principle of statutory construction by which the mention of certain items implies the exclusion of unmentioned others. 
Code of Civil Procedure provisions with respect to civil actions, and unless a compensation proceeding can be classified not only as a civil action, but as one of the particular types of civil action mentioned in Chapter 3 of Title II of Part Two of the Code of Civil Procedure, the suspension of the statute of limitations in favor of prisoners cannot be deemed to apply to applicants for workmen's compensation benefits.

Effect of Statutory Provisions-It may be concluded, then, that under the statute of limitations of the workmen's compensation law, imprisonment does not suspend the running of time against a compensation claim. It seems reasonable to conclude, also, that provisions of the Code of Civil Procedure which make imprisonment the basis for suspending statutory limitations of time in civil actions have no application to compensation proceedings. If deemed applicable, such provisions could suspend the statute only as to those prisoners serving time (1) when the cause of action accrues, and (2) for a term less than life $;^{53}$ and therefore would not prevent the running of the statutory period in causes of action accruing before the confinement of the prisoner, nor in cases where the felon was sentenced to death or to life imprisonment.

County Jail Prisoners-It seems clear that the statute of limitations continues to run against county jail prisoners under all conditions. Such prisoners are not deprived of their civil rights by their incarceration, and therefore retain the same right to institute and maintain litigation as they previously possessed. Jail confinement is not recognized by the workmen's compensation law as a disability suspending the limitations of time. Nor could Code of Civil Procedure provisions, if deemed applicable, benefit jail prisoners for the latter cannot acquire the status of employees during their imprisonment, and the Civil Procedure provisions do not stay limitations of time as to preexisting causes of action. ${ }^{60}$

State Convicts-The result appears to be the same for prisoners in state institutions. Their legal disability does not constitute a basis for interference with the running of the statute of limitations, under either the compensation law itself or by reason of general statutory provisions, although the latter, if deemed applicable, would suspend

58 Cal. Codf, Crv. Proc. \$352.

59 See discussion of this point at pages 169 and 171 , supra.

co Supra note 55 and text thereto. 
the limitations of time as to injuries sustained by prisoners while serving less than a life sentence.

Parolees-As previously noted, a paroled convict is constructively a prisoner and has the civil status of one. Unless his right to sue is among the civil rights restored by the terms of his parole, the effect of the statute of limitations upon a parolee must necessarily be the same as upon any unreleased state convict. With the restoration of the right to sue, the parolee resumes the status of an ordinary citizen so far as the limitations of time are concerned. In either event, it must be concluded that the operation of the statute of limitations is not affected by the status of a paroled convict.

\section{Summary of Conclusions}

Status as Employee--As a general rule, a prisoner cannot acquire the status of an employee within the meaning of the compensation law during the period of his incarceration. Jail prisoners are not employees under any circumstances, and a state convict may become an employee only when granted a parole which expressly or by reasonable implication restores the civil right of contracting for his own services. The usual form of general parole contains such a restoration of the right to engage in employment. A limited parole, granted solely to permit the prisoner for a restricted period to engage in one of the special forms of employment provided for by the Penal Code, only accomplishes temporary restoration of a restricted right to resume the employee status, where such a status is specifically authorized by statute, or at least is not forbidden thereby.

Status as Litigant-The right to sue is a civil right which is denied by statute to state convicts, but not to jail prisoners. The latter, therefore, are free to file and prosecute their compensation claims at all times. State convicts are deprived of the right to press a claim for compensation benefits until, by one of the procedures prescribed by the Penal Code, the right to sue is restored. The statute of limitations runs against jail prisoners and state convicts alike, and Code of Civil Procedure provisions which in civil actions suspend operation of the statute of limitations as to prisoners are not applicable to compensation claims. 